\title{
Analytical Relevance of Trace Metal Speciation in Environmental and Biophysicochemical Systems
}

\author{
Nsikak U. Benson*, Winifred U. Anake, Ifedolapo O. Olanrewaju \\ Environmental Chemistry Research Group, Department of Industrial Chemistry, Covenant University, Ota, Nigeria \\ Email: "nbenson@covenantuniversity.edu.ng
}

Received August 24, 2013; revised September 26, 2013; accepted October 14, 2013

Copyright (C) 2013 Nsikak U. Benson et al. This is an open access article distributed under the Creative Commons Attribution License, which permits unrestricted use, distribution, and reproduction in any medium, provided the original work is properly cited.

\begin{abstract}
This article presents a review of the analytical relevance of trace metal speciation analysis, which must be considered in environmental and biophysicochemical systems for reliable and efficient assessment and monitoring of trace metals. Examples are given of methodological approaches used for speciation analysis. An overview of speciation analysis in sediments, aquatic ecosystems and agrosystems is also presented.
\end{abstract}

Keywords: Trace Metals; Speciation; Speciation Analysis; Sediments; Water; Agrosystems

\section{Introduction}

Trace metals are introduced anthropogenically as micropollutants into our environment from several sources such as industrial, agricultural and domestic wastewater/ effluents [1]. Over the years, their fate, transport and pollution in the environment especially the aquatic ecosystems are becoming an environmental problem of concern owing to their ecotoxic properties. The biological activity and availability, biogeological fate, transport and eventual effect of trace metals in the environment and biological systems are a function of the chemical species in which they occur [2].

In trace metal chemistry, it is a common practice to simply quantify trace metal contents in samples of interest as total level or concentration. In recent times, increased attention has been given to the determination and quantification of trace metals when assessing their impacts in environmental systems (air, water, soil and biota) in this form. Growing evidence indicates that the determination of the total trace metal concentration in soil $[3,4]$, sediments $[5,6]$, marine and fresh waters $[6,7]$, biota $[8,9]$, and consumer products [10] principally highlights simplified ways of expressing measures of metal pollution in matrix of interest. Although these procedural assessments are scientifically recognized, they have proved deficient in presenting trace metals in their physicochemical forms as well as predicting their toxicity [11]. The analysis and quantification of trace metals in

${ }^{*}$ Corresponding author. environmental and biological systems of interest as total concentration are seemingly tenable but misleading, and therefore requires complementary partitioning information, which will characteristically elucidate the different elemental coexisting forms.

However, considering the enhanced understanding of biological, metabolic and toxicological effects of these trace metals, it has become necessary to measure trace metals as "total" as well as determine quantitatively the different chemical forms of these trace metals. This is necessary since toxicity of trace elements especially alkylated and organometals is a function of their speciation coefficient [2]. Thus, chemical speciation analysis has become an efficient and reliable tool for assessment of environmental and ecotoxicological risks posed by trace metals. Partitioning studies of heavy metals in water and sediments have emerged as an important instrument in environmental toxicological researches. In recent times, it has become the core of metal pollution studies through which heavy metal species have been harnessed in determining their potential bioavailability and remobilization within human, sedimentary, biotic and aquatic systems. The greatest interest in metal speciation in natural environments and biosystems is probably explained by their influence on the bioavailability and toxicity of metals.

\subsection{A Review of Current Usage of the Terms "Speciation" and "Speciation Analysis"}

Although there is a discernable difference between the 
terms "speciation" and "speciation analysis", there still exists some form of confusion on their usage by environmental and analytical chemists, biologists, geochemists, and in evolutionary concept. However, in order to avoid confusion, an attempt is made to clearly define these terms. According to IUPAC, speciation in chemistry simply refers to the distribution of an element amongst defined chemical species, while speciation analysis describes the analytical activities of identifying and/or measuring the quantities of one or more individual chemical species or forms in an environmental or biosystems [12].

Furthermore, for chemical elements, the chemical species refers to the specific form(s) of the element present in terms of oxidation or electronic state, isotopic composition and molecular structure. The distribution and bioavailability of trace metals in environmental samples such as soil, sediments, water, atmospheric particulate and biospecimens can be considered to obtain a better understanding of environment-organism interactions. Thus, bioactivity and bioavailability of trace metals strictly depend on their chemical coexisting forms, and therefore their speciation [13]. The determination of total metal concentration in living systems, environmental substances and biospecimens is not sufficient to assess the environmental impact of polluted sediments since heavy metals may have different chemical forms and only a fraction can be remobilized easily [2,14]. Studies on the distribution and speciation of heavy metals in sediments can provide not only information on the degree of pollution, but especially the actual environmental impact on metal bioavailability as well as their origin [14].

There are many possible approaches to trace metal speciation. These include the spectral characterization, kinetic, direct species-specific, computational and hybrid techniques, among others. Several contemporary techniques are being developed or improved upon earlier procedures. However, the choice of any of these approaches is subject to the nature and physical properties of the elemental species to be determined. To date, it has generally been accepted that the most appropriate method to evaluate heavy metals is the selective sequential extraction procedures [15]. Selective extractions are widely used in soil and sediment analysis to evaluate long-term potential emission of pollutants and to study the distribution of pollutants among the geochemical phases [16]. They are also used to determine the metals associated with source constituents in sedimentary deposits. According to [17], metals with an anthropogenic origin are mainly extracted in the first step of the procedure, while lithogenic metals are found in the last step of the process corresponding to the residual fraction [14].

In environmental and biophysicochemical systems, the geochemistry, bioavailability and toxicity of trace metals are a function of the physicochemical characteristics of the forms in which it is present. Additionally, the physiological characteristics of an organism constitute important factors that influence its speciation. However, biological availability of a trace metal is not a function of total metal concentration, but rather of particular species of the metal that can either interact directly with an organism or can convert readily to species which can interact (the kinetically labile metal concentration) $[2,14]$.

\subsection{Analytical Significance of Trace Metal Speciation}

Analytical measurements expressed as total content of specific metal in an environmental and biological material are insufficient. Therefore, one of the most important significance of speciation analysis is the qualitative and quantitative signature it has given to specific metal species, which could be employed in the assessment of the index of toxicity impacts of elements. Speciation analysis is an important present-day analytical tool particularly used for the elucidation of the chemical form(s) as well as the quantitative estimation of a specific element when conducting toxicological and biochemical investigations.

After years of considerable researches on metals pollution, it is now widely held that the distribution, mobility, bioavailability and toxicity of trace metals in environmental and biological systems depend not simply on their concentrations, but critically on their chemical forms. It is also known that individual metal species possesses a different chemical activity and ability to transform. Therefore, for proper estimation of the degree of the toxic effect of metals, their distribution among coexisting forms in aquatic environment must be known. This is realized through the use of metal speciation analysis. Thus, speciation analysis can increase the information capacity of collected results via characterizing in detail some of the most important chemical forms of an element in order to understand the transformations between forms that are likely to occur, and to infer from such information the probable environmental and health consequences.

Trace metal speciation analysis is an important environmental analytical tool for forecasting metal fate in aquatic ecosystems and developing effective methods for water quality monitoring. Chemical compounds that differ in isotopic composition, conformation, oxidation or electronic state, or in the nature of their complexed or covalently bound substituents can be regarded as distinct chemical species [12]. In the light of this, a systematic approach highlighting identifiable species and distinct transient forms of an element, its coordinated atoms or excited states structurally could be categorized into nuclear (isotopic) composition, electronic or oxidation state, 
inorganic, organic and macromolecular compounds and complexes.

\subsection{Techniques, Types of Speciation Analysis and Their Applications}

The toxicity and bioavailability of heavy metals are not only a function of their total concentration in water, but also a function of the concentration and ratio of the various coexisting forms $[18,19]$. However, estimation and elaborate quantification of these free metal species can be achieved through one of the predominant trends of heavy metal analysis-elemental speciation, which employs various speciation techniques. Although the various schemes developed by several researchers are capable of quantifying the amount of free and bound metal, it has been noted that only the most sensitive techniques are suitable for speciation analysis. According to [20], speciation techniques using inductively coupled plasma mass spectrophotometry (ICP-MS), inductively coupled plasma atomic emission spectrophotometry (ICP-AES), and electrothermal atomic absorption spectrometry (ETAAS) could be considered as the most sensitive and selective techniques.

However, continuing developments in analytical chemistry have provided a platform for the proliferation of investigations that have now seen the coupling of versatile separation techniques, such as high performance liquid chromatography, gas chromatography and capillary electrophoresis (CE) to a highly sensitive detector, such as ICP-MS, which has generated substantial attractive analytical tools for ultra-trace elemental speciation analysis [21].

The extraction, detection and ultratrace quantitative and qualitative determinations of elements through speciation analysis can be carried out in five different ways [15]. However, the choice of any of the five types is a function of the aim and scope of the analytical investigation. A concise summary of the basic types of speciation analysis commonly encountered in chemical analysis, their characteristics, areas and examples of where the speciation analysis principles could be applied is presented in Table 1.

\section{Speciation Studies in Different Environmental Strata}

\subsection{Speciation Studies in Sediment}

Phase-selective chemical extractions or fractionation schemes involving multistep extraction procedures is one of the approaches employed for understanding metal speciation especially in sediment analysis [22-24]. A typical fractionation scheme is the procedure developed by [22], which delineates the metal species sequentially as exchangeable, carbonate-bound, iron and manganese oxide-bound, organically-bound and residual. Soil, sediments or precipitates are known reservoirs or sinks of trace metals in the environments, and the metals may be present in several different physicochemical forms/phases [25-27]. These phases are water soluble, exchangeable; specifically adsorbed; carbonate; secondary Fe and Mn oxides; organic matter; sulphides and silicates [28]. This procedure that was originally developed as a pivotal heavy metal speciation scheme using extracting agents has evolved as the foundation for recent advances in fractionation speciation schemes. The sequential extraction or fractionation schemes are a very useful method, for characterizing solid phases associated trace elements in soils, sediments or particulates [29-33]. It must be pointed out that the extracting reagents employed in speciation analysis are chosen based on their selectivity and specificity towards a particular physicochemical species of trace metal [28]. The reagents cocktail for respective extraction steps are capable of disrupting the binding agents between individual element and the sediments thus allowing possible release of metal species into the solution. A typical multistep sequential extraction scheme is shown in Table 2.

More so, a modified sequential chemical extraction procedure developed by [36] for partitioning studies of particulate bound cadmium in soil was conveniently classified into eight fractions vis-à-vis: exchangeable, carbonate-bound, metal-organic complex-bound, easily reducible metal oxide-bound, organic-bound, amorphous mineral colloid-bound, crystalline Fe oxide-bound, and residual fractions (Table 3 ).

However, following the pioneering research by [22], a relatively large number of fractionation schemes have been developed, which employ series of reagents to separate individual fractions of trace metals. In general, sequential extraction procedures have not been standardized therefore compelling individual researchers to use schemes developed through their effort. However, in order to streamline speciation analysis for repeatability and reproducibility through harmonization and standardization of extraction protocol, a sequential extraction method has been developed by the Standards, Measurements and Testing Programme (formerly Community Bureau of Reference, BCR) of the Commission of European Communities. In this three-stage sequential extraction procedure, trace metals are divided into acid-soluble/exchangeable, reducible and oxidisable fractions, which are leached with reagents. A summary of this approach is presented in Table 4 [37-39].

A modification of this method into a four-stage sequential leaching procedure has been developed and applied to assess the bioavailability and environmental mo- 
Table 1. Basic types of speciation analysis and application in chemical analysis [15].

\begin{tabular}{|c|c|c|c|}
\hline Type of speciation & Characteristics & Areas of application & Example(s) of application \\
\hline 1. Physical Speciation & $\begin{array}{l}\text { Involves the determination of the different } \\
\text { forms of the same chemical species. }\end{array}$ & $\begin{array}{l}\text { Air, water and soil } \\
\text { pollution analyses. }\end{array}$ & $\begin{array}{l}\text { a) Trace metals analysis } \\
\text { (soluble and suspended fraction). } \\
\text { b) Trace metals analysis of different } \\
\text { forms present in soil and sediment after } \\
\text { sequential extraction. }\end{array}$ \\
\hline 2. Chemical Speciation & Involves determination of chemical species. & & \\
\hline \multirow{2}{*}{$\begin{array}{l}\text { 2.1 Screening Speciation } \\
\text { 2.1.1 Distribution Speciation }\end{array}$} & $\begin{array}{l}\text { A type of chemical speciation that involves } \\
\text { the extraction, detection and determination } \\
\text { of a specific chemical species or analyte. }\end{array}$ & $\begin{array}{l}\text { a) Air, water and soil } \\
\text { pollution analyses. } \\
\text { b) Food contamination } \\
\text { studies. }\end{array}$ & $\begin{array}{l}\text { a) Determination of tributyltin (TBT) } \\
\text { or triphenyltin (TPhT) in environmental } \\
\text { biota, sediments, seawater, etc. } \\
\text { b) Determination of methylmercury } \\
\text { in fish tissue or lead in food products. }\end{array}$ \\
\hline & $\begin{array}{c}\text { A type of screening speciation that involves } \\
\text { the detection and determination selected chemical } \\
\text { individual in particular elements of analyzed } \\
\text { sample. Usually employed in analyses of } \\
\text { biological samples. }\end{array}$ & $\begin{array}{l}\text { a) Air, water and soil } \\
\text { pollution analyses. } \\
\text { b) Ecotoxicological } \\
\text { studies. }\end{array}$ & $\begin{array}{l}\text { a) Trace metals analyses especially } \\
\text { in blood serum and cells. } \\
\text { b) Determination of trace metals } \\
\text { in plants samples. }\end{array}$ \\
\hline \multirow{2}{*}{$\begin{array}{l}\text { 2.2 Group Speciation } \\
\text { 2.2.1 Individual Speciation }\end{array}$} & $\begin{array}{c}\text { This is a type of chemical speciation that leads } \\
\text { to the extraction, detection and determination of } \\
\text { a set or group of analytes that possess a definite } \\
\text { set of characteristics; or the specific group of } \\
\text { compounds or trace metals existing in different } \\
\text { compounds and forms and at the specific } \\
\text { oxidation level. }\end{array}$ & $\begin{array}{l}\text { a) Air, water and soil } \\
\text { pollution analyses. } \\
\text { b) Ecotoxicological } \\
\text { studies. } \\
\text { c) Food contamination } \\
\text { studies. }\end{array}$ & $\begin{array}{l}\text { a) Determination of redox forms of } \\
\text { chromium, Cr(VI) in environmental } \\
\text { pollution analyses. } \\
\text { b) Determination of elementary, inor- } \\
\text { ganic and organic forms of mercury in } \\
\text { the environment and food products. }\end{array}$ \\
\hline & $\begin{array}{l}\text { A type of group speciation that involves the extrac- } \\
\text { tion, detection and determination of all chemical } \\
\text { species in analyzed sample. }\end{array}$ & $\begin{array}{l}\text { a) Air, water and soil } \\
\text { pollution analyses. } \\
\text { b) Ecotoxicological } \\
\text { studies. } \\
\text { c) Food contamination } \\
\text { studies. }\end{array}$ & $\begin{array}{l}\text { a) Identification and determination } \\
\text { of chemical species defined as to } \\
\text { molecular, complex, electronic or } \\
\text { nuclear structure. }\end{array}$ \\
\hline
\end{tabular}

Table 2. Multistep phase-selective extraction schemes for metal speciation [34,35].

\begin{tabular}{|c|c|c|c|}
\hline Steps & Species & Reagent & Extraction time/temp. \\
\hline I & Exchangeable & $\begin{array}{c}20 \mathrm{ml} 1 \mathrm{M} \mathrm{MgCl}_{2}(\mathrm{pH}=7), \\
1 \mathrm{M} \text { ammonium acetate }(\mathrm{pH}=7)\end{array}$ & $\begin{array}{l}30 \mathrm{~min} \\
10 \mathrm{~min}\end{array}$ \\
\hline II & Carbonates or specifically adsorbed & $1 \mathrm{M}$ sodium acetate $(\mathrm{pH}=5)$ & $300 \mathrm{~min}$ \\
\hline III & Mn oxide-bound & $0.1 \mathrm{M} \mathrm{NH}_{4} \mathrm{OH} \cdot \mathrm{HCl}$ in $0.01 \mathrm{M} \mathrm{HNO}_{3}$ & 30 min (Room temp.) \\
\hline IV & Fe-Mn oxide-bound & $0.04 \mathrm{M} \mathrm{NH}_{4} \mathrm{OH} \cdot \mathrm{HCl}$ in $25 \%(\mathrm{v} / \mathrm{v})$ acetic acid & $360 \min \left(96^{\circ} \mathrm{C}\right)$ \\
\hline $\mathrm{V}$ & $\begin{array}{l}\text { Organically- and } \\
\text { sulphides-bound }\end{array}$ & $30 \% \mathrm{H}_{2} \mathrm{O}_{2}\left(\mathrm{pH}=2\right.$ with $\left.\mathrm{HNO}_{3}\right)$, then $3.2 \mathrm{M}$ sodium acetate in $20 \%(\mathrm{v} / \mathrm{v}) \mathrm{HNO}_{3}$ & $\begin{array}{l}300 \min \left(85^{\circ} \mathrm{C}\right) \\
\text { Room temp. }\end{array}$ \\
\hline VI & Residual & Digestion with $\mathrm{HF}-\mathrm{HClO}_{4}(5: 1)$ ratio & \\
\hline
\end{tabular}

Table 3. Multistep sequential extraction schemes for metal speciation [36].

\begin{tabular}{|c|c|c|c|}
\hline Steps & Species & Reagent & Extraction time/temp. \\
\hline I & Exchangeable & $10 \mathrm{ml} \mathrm{Mg}\left(\mathrm{NO}_{3}\right)_{2}(\mathrm{pH}=7), 1 \mathrm{M}$ ammonium acetate $(\mathrm{pH}=7)$ & $4 \mathrm{~h}$ at $25^{\circ} \mathrm{C}$ \\
\hline II & Carbonate-bound & $25 \mathrm{ml} 1 \mathrm{M}$ sodium acetate $(\mathrm{pH}=5)$ & $6 \mathrm{~h}$ at $25^{\circ} \mathrm{C}$ \\
\hline III & Metallic organic complex-bound & $30 \mathrm{ml} 0.1 \mathrm{M}$ sodium pyrophosphate $\left(\mathrm{Na}_{4} \mathrm{P}_{2} \mathrm{O}_{7} \cdot 10 \mathrm{H}_{2} \mathrm{O}\right)(\mathrm{pH}=10)$ & $20 \mathrm{~h}$ at $25^{\circ} \mathrm{C}$ \\
\hline IV & Easily reducible metal oxide-bound & $20 \mathrm{ml} 0.01 \mathrm{M} \mathrm{NH} \mathrm{NH}_{2} \mathrm{OH} \cdot \mathrm{HCl}$ in $0.01 \mathrm{M} \mathrm{HNO}_{3}$ & $30 \min$ at $25^{\circ} \mathrm{C}$ \\
\hline $\mathrm{V}$ & $\mathrm{H}_{2} \mathrm{O}_{2}$ extractable organic-bound & $\begin{array}{c}5 \mathrm{ml} 30 \% \mathrm{H}_{2} \mathrm{O}_{2}\left(\mathrm{pH}=2 \text { with } \mathrm{HNO}_{3}\right) \text {, then } 3 \mathrm{ml} 0.02 \mathrm{M} \mathrm{HNO}_{3} \\
\text { Add } 3 \mathrm{ml} 30 \% \mathrm{H}_{2} \mathrm{O}_{2}\left(\mathrm{pH}=2 \text { with } \mathrm{HNO}_{3}\right) \text {, cool and add } 10 \mathrm{ml} \\
2.0 \mathrm{M} \mathrm{Mg}\left(\mathrm{NO}_{3}\right)_{2} \text { in } 20 \% \mathrm{HNO}_{3}\end{array}$ & $\begin{array}{c}2 \mathrm{~h} \text { at } 85^{\circ} \mathrm{C} \\
4 \mathrm{~h} \text { at } 25^{\circ} \mathrm{C}(\text { dark })\end{array}$ \\
\hline VI & Amorphous mineral colloid-bound & $10 \mathrm{ml} 0.2 \mathrm{M}\left(\mathrm{NH}_{4}\right)_{2} \mathrm{C}_{2} \mathrm{O}_{4}(\mathrm{pH}=3)$ & $4 \mathrm{~h}$ at $25^{\circ} \mathrm{C}$ (dark) \\
\hline VII & Crystalline Fe oxide bound & $25 \mathrm{ml} 0.2 \mathrm{M}\left(\mathrm{NH}_{4}\right)_{2} \mathrm{C}_{2} \mathrm{O}_{4}(\mathrm{pH}=3)$ in $0.1 \mathrm{M}$ ascorbic acid & $30 \mathrm{~min}$ at $95^{\circ} \mathrm{C}$ \\
\hline VII & Residual & Digestion with $\mathrm{HF}-\mathrm{HClO}_{4}(5: 1)$ ratio & \\
\hline
\end{tabular}


Table 4. Three-step sequential extraction procedure developed by BCR [37-39].

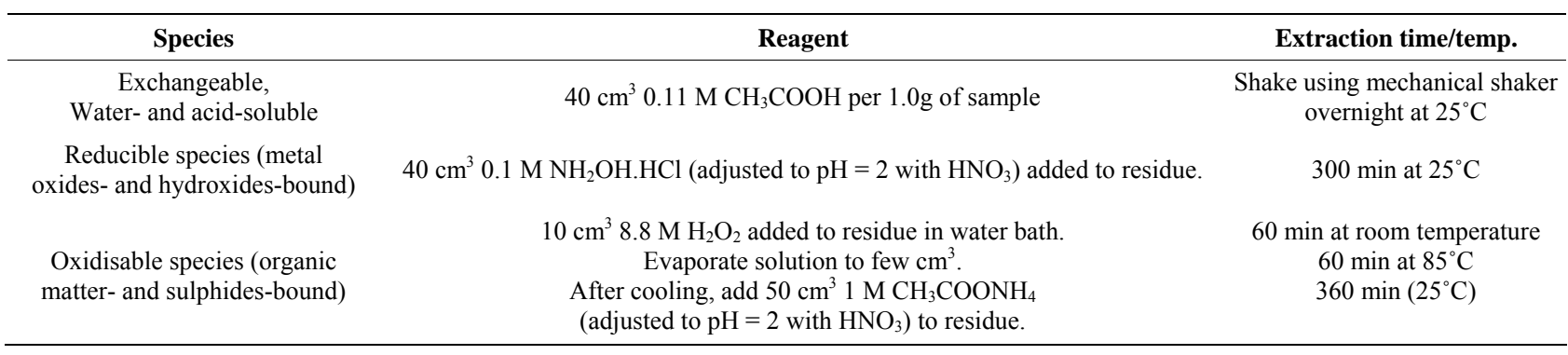

bility of some heavy metals in total suspended particulates [40].

\subsection{Speciation Studies in Aquatic Ecosystems}

It is widely known that pollutants such as trace metals are introduced into aquatic ecosystems mainly through natural and anthropogenic sources. The weathering of rocks and volcanic eruptions are among the natural sources, while aerial deposition from automotive traffic and power plants, mining, industrial activities, urbanization, and agricultural activities constitute human-induced sources [41-43]. Human-induced emissions and inputs into freshwater, estuarine, seawater or ocean systems can give rise to higher concentrations of the metals relative to the natural threshold concentrations. Once these contaminants enter into freshwater or marine ecosystems, they are capable of distributing into water, sediment, and biota compartments. In most cases, the overabundance of heavy metals even in trace levels in surface or mixed layer water could develop a metal pollution ecological footprint capable of posing serious health risks to sea fauna and flora, humans, and in general to the environment. In aquatic ecosystems such as estuaries, rivers, streams, and oceans, the determination of the total concentrations of heavy metals in surface water and sediment is a useful analytical tool in identifying pollution hotspots as well as the identification of human-mediated sources of metal inputs, whereas speciation studies is a multipurpose useful tool in determining the bioavailability and toxicity of heavy metals, and in understanding the pollution regimes and metal-sediment diffusive fluxes or interactions in aquatic systems $[44,45]$.

All heavy metals exist in surface waters in colloidal, particulate, and dissolved phases, although dissolved concentrations are generally low [46]. The colloidal and particulate metal may be found in 1) hydroxides, oxides, silicates, or sulfides; or 2) adsorbed to clay, silica, or organic matter. The soluble forms are generally ions or unionized organometallic chelates or complexes. The solubility of trace metals in surface waters is predominately controlled by the water $\mathrm{pH}$, the type and concentration of ligands on which the metal could adsorb, and the oxidation state of the mineral components and the redox environment of the system.

The distribution of trace metals in aquatic substrates such as sediment, surface water, and microorganisms has been identified as exchangeable, carbonates, oxidizing, organic matter and residual fractions $[22,47,48]$. Studies have shown that the physicochemical forms of trace metals determine their potential bioavailability and remobilization in aquatic systems $[1,11]$. However, the chemical speciation of metals could be made possible by changing ecohydrological perturbations, or as the organic particulates binding the metals ultimately decompose $[1$, 49]. Trace metals in different sequential extraction aside reflecting the metal component or integrity of an ecosystem could be used to realize the chemical behavior with respect to remobilization.

In the estuaries, partitioning studies are particularly important because metal speciation is influenced by the constantly changing environmental conditions including salinity, $\mathrm{pH}$ and sediment redox potential $[43,50,51]$. The speciation of dissolved metals in seawater is relatively well understood. It is known, for example, that free ions of $\mathrm{Cu}$ and $\mathrm{Cd}$ are the most bioavailable inorganic forms and account for only a small proportion of the total dissolved metal concentration [52].

\subsection{Speciation Studies in Agrosystems}

Heavy metals are found naturally in undisturbed soils and, in fact, small amounts of many metals are required by plants as micro- and macronutrients to remain healthy. The sources of heavy metals in soils are primarily anthropogenic, although some are known to occur naturally, but rarely at toxic levels. Human induced activities have dramatically modified the composition and organization of soils. Non-regulated large-scale disposal of municipal sludge, domestic, urban and industrial wastes, agricultural application, manufacturing and mining activities have resulted in increased heavy metal contamination of urban and agricultural soils. Other potential sources of human-induced soil contamination with heavy metals include industrial and traffic dust emitted into the atmosphere, land application of domestic or industrial sewage sludge, mineral, mainly phosphorous, fertilizers and pesticides $[38,53,54]$. However, these sources are 
capable of creating patchy hotspots of metal contamination, which could be of high concern and pose possible dangers to human and animals in contact with the contaminated soils [55].

Excess heavy metal accumulation in the agrosystems is toxic to humans and other animals. Unlike organic contaminants, most metals in the soil environment do not undergo breakdown by microbial organisms or chemical degradation, and therefore concentrations of metals persist in soils for a long time after their input [56]. Once metals find their way into the soil, they could remain in the soil environment, or bioaccumulate and biotransform in plants and food chain, and as well as get seeped into groundwater [57]. These biopersistence, bioaccumulative and biotransformative properties could lead to enhanced levels of heavy metals in soils, and subsequent bioavailability and uptake by plants. However, this depends not only on heavy metal contents in soils but is also governed by factors such as soil $\mathrm{pH}$, organic matter and clay contents [58].

Trace metal pollution of soils is a pervasive problem that often constitutes serious short- and long-term risks for humans, plants, groundwater quality and ecosystem health. Several researches have been reported on heavy metal contamination in agrosystems especially arising from human-mediated sources such as industrial waste, automobile emission, mining or processing activities, and agricultural practice [59]. Majority of these researches are based on analytical quantifications that reports heavy metal concentrations as the total content of metals in analyzed matrices. Fewer attempts have been made to evaluate and report the speciation of heavy metals in particulate species [15,22]. Moreover, the expression of heavy metal contents as "total" concentration to assess the quality of metal pollution in agrosystems is misleading and analytically uninformative. Information about the fate and toxicity of heavy metals in a contaminated soil could be sufficiently highlighted through speciation analyses of soil samples $[60,61]$. In the light of the foregoing, it is imperative that in monitoring studies and risk assessments of metal contaminated soils, not only the total or extractable contents should be considered, but also the chemical forms (species) of the metal contaminants must be known. Such studies may help to minimize human health risks associated with trace metals contamination and aid in the evaluation of their bioavailability [62].

Metal bioavailability in different soils, however, depends on soil properties such as the $\mathrm{pH}$, metal contents, particle size, organic matter, and wetness. A research report has indicated that the mobility, bioavailability, storage, retention and toxicity of trace metals in living organisms, food and the environment is a function of the chemical forms in which they enter the ecosystems and the final forms in which they are present therein [63]. Therefore, in order to determine the binding forms of heavy metals in soil, it is imperative that chemical extraction procedures should be employed. A large number of sequential extraction procedures, which utilizes series of reagents to separate individual fractions of heavy metals have been developed, majority of which are derived from the pioneering studies by [22].

Speciation analysis of trace elements in soils may be performed using either physical or chemical methods, but the latter offers a reliable and more sensitive approach. The chemical protocols basically employ chemical solutions of varying, but specific, strengths and reactivities to release heavy metals from the different fractions of soil samples of interest as a means of quantifying the coexisting metal species [64]. Elemental quantification in soils can be achieved through single reagent leaching, ion exchange resins, and sequential extraction procedures. The theory involved in the latter is that the most mobile metals are leached in the first fraction and continue in order of decreasing of mobility. Common examples of the sequential extraction techniques are the Tessier Procedure, the Community Bureau of Reference (BCR) Procedure, the Maiz Short Extraction Procedure, the Galán Procedure, and the Geological Society of Canada Procedure [24,65-67]. These sequential extraction procedures promote fractionation. However, despite that a number of extraction schemes have been proposed and developed by several researchers, there abound controversies regarding some of the sequential techniques. Nevertheless, the Tessier Procedure is generally accepted as the most commonly used protocol followed closely by the Community Bureau of Reference Procedure, although it is still plagued by limitations.

\section{Conclusion and Future Perspectives}

Although studies on trace metal speciation has been active for decades, the field has been instrument and method limited. However, in recent times, the number of research carried out on trace metal speciation has increased considerably with the improvement of existing methodologies, recent advances on hyphenated systems and the development of in situ automated monitoring profilers that are capable of monitoring specific fractions of trace metals. Nevertheless, new and universally accepted, reliable and cost effective analytical tools capable of performing in situ, real-time monitoring with minimum perturbation of the environmental matrix should be developed. This paper examined the analytical relevance and the need for trace metal speciation in environmental and biochemical systems in order to determine the distribution of specific species present for a better understanding of their degree of toxicity, mobility and stability. Judging from the foregoing, the use of speciation of ele- 
ments to assess the bioavailability and mobility of heavy metals in environmental and biophysicochemical systems remains a sine qua non for a better understanding of the different chemical forms of a particular element or its compounds and associated patterns of toxicity. It is therefore suggested that researchers should adopt the speciation analysis while conducting the assessment of trace metals in order to be able to obtain and proffer additional useful information on species of differing carcinogenic potential in biosystems and environmental matrices in preference to total metal determination.

\section{REFERENCES}

[1] N. Benson, E. D. Udosen and O. Akpabio, "Interseasonal Distribution and Partitioning of Heavy Metals in Subtidal Sediment of Qua Iboe Estuary and Associated Creeks, Niger Delta (Nigeria)," Environmental Monitoring and Assessment, Vol. 146, No. 1-3, 2008, pp. 253-265. http://dx.doi.org/10.1007/s10661-007-0077-5

[2] A. Sanz-Medel, "Toxic Trace Metal Speciation: Importance and Tools for Environmental and Biological Analysis," Pure and Applied Chemistry, Vol. 70, No. 12, 1998, pp. 2281-2285.

http://dx.doi.org/10.1351/pac199870122281

[3] N. U. Benson, "Lead, Nickel, Vanadium, Cobalt, Copper and Manganese Distributions in Intensely Cultivated Floodplain Ultisol of Cross River, Nigeria," International Journal of Soil Science, Vol. 1, No. 2, 2006, pp. 140-145. http://dx.doi.org/10.3923/ijss.2006.140.145

[4] M. I. Yahaya, G. C. Ezeh, Y. F. Musa and S. Y. Mohammad, "Analysis of Heavy Metals Concentration in Road Sides Soil in Yauri, Nigeria," African Journal of Pure and Applied Chemistry, Vol. 4, No. 3, 2010, pp. 22-30.

[5] E. D. Udosen, N. U. Benson and J. P. Essien, "Trends in Heavy Metals and Hydrocarbon Burdens in Stubbs Creek, A Tributary of the Qua Iboe River Estuary, Nigeria," Trends in Applied Sciences and Research, Vol. 2, No. 4, 2007, pp. 312-319. http://dx.doi.org/10.3923/tasr.2007.312.319

[6] J. P. Essien, S. P. Antai and A. A. Olajire, "Distribution, Seasonal Variations and Ecotoxicological Significance of Heavy Metals in Sediments of Cross River Estuary Mangrove Swamp," Water, Air and Soil Pollution, Vol. 197, No. 1-4, 2009, pp. 91-105. http://dx.doi.org/10.1007/s11270-008-9793-x

[7] N. U. Benson, J. P. Essien and D. E. Bassey, "Hydrobiological Constraints of Trace Metals in Surface Water, Coastal Sediments and Water Lily of Calabar River, Nigeria," African Journal of Biotechnology, Vol. 6, No. 20, 2007, pp. 2358-2362.

[8] O. O. Ayejuyo, O. O. Tovide and B. O. Moronkola, "Heavy Metal Distribution in Crab (Callinectes amnicola) Living on the Shores of Ojo Rivers, Lagos, Nigeria," Environmentalist, Vol. 29, No. 1, 2009, pp. 33-36. http://dx.doi.org/10.1007/s10669-008-9177-1

[9] D. S. Abolude, O. A. Davies and D. W. Avong, "Level of Heavy Metals in Freshwater Crab (Cardisoma guahumi)
Obtained from Ahmadu Bello University Reservoir, Zaria Nigeria," International Journal of Animal and Veterinary Advances, Vol. 1, No. 2, 2009, pp. 54-58.

[10] J. A. Omolaoye, A. Uzairu and C. Gimba, "Heavy Metal Assessment of Some Soft Plastic Toys Imported into Nigeria from China," Journal of Environmental Chemistry and Ecotoxicology, Vol. 2, No. 8, 2010, pp. 126-130.

[11] A. O. Ibhadon, P. Wright and R. Daniels, "Trace Metal Speciation and Contamination in an Intertidal Estuary," Journal of Environmental Monitoring, Vol. 6, No. 8, 2004, pp. 679-683. http://dx.doi.org/10.1039/b315954j

[12] D. M. Templeton, F. Ariese, R. Cornelis, L-G. Danielsson, H. Muntau, H. P. Van Leeuwen and R. Łobiński, "Guidelines for Terms Related to Chemical Speciation and Fractionation of Elements: Definitions, Structural Aspects, and Methodological Approaches," Pure and Applied Chemistry, Vol. 72, No. 8, 2000, pp. 1453-1470. http://dx.doi.org/10.1351/pac200072081453

[13] B. Jones and A. Turki, "Distribution and Speciation of Heavy Metals in Surficial Sediments from Tees Estuary, Northeast England," Marine Pollution Bulletin, Vol. 34, No. 10, 1997, pp. 768-779. http://dx.doi.org/10.1016/S0025-326X(97)00047-7

[14] M. Ramirez, S. Massolo, R. Frache and J. Correa, "Metal Speciation and Environmental Impact on Sandy Beaches Due to El Salvador Copper Mines, Chile," Marine Pollution Bulletin, Vol. 50, No. 1, 2005, pp. 62-72. http://dx.doi.org/10.1016/j.marpolbul.2004.08.010

[15] A. Kot and J. Namiesnik, "The Role of Speciation in Analytical Chemistry, "Trends in Analytical Chemistry, Vol. 19, No. 2-3, 2000, pp. 69-79. http://dx.doi.org/10.1016/S0165-9936(99)00195-8

[16] G. Rauret, J. López-Sánchez, A. Sahuquillo, R. Rubio, C. Davidson, A. Ure and P. Quevauviller, "Improvement of the BCR three Step Sequential Extraction Procedure Prior to the Certification of New Sediment and Soil Reference Materials," Journal of Environmental Monitoring, Vol. 1, No. 1, 1999, pp. 57-61. http://dx.doi.org/10.1039/a807854h

[17] R. Rubio, J. Lopez-Sanchez and G. Ruaret, "La Especiacion Solida de Trazas de Metales en Sedimentos. Aplicacion a Sedimentos muy Contaminados," Anales de Química, Vol. 87, 1991, pp. 599-605.

[18] D. M. Templeton, "Biomedical Aspects of Trace Element Speciation," Fresenius' Journal of Analytical Chemistry, Vol. 363, No. 5-6, 1999, pp. 505-511. http://dx.doi.org/10.1007/s002160051234

[19] R. P. Linnik and O. A. Zaporozhets, "Solid-Phase Reagent for Molecular Spectroscopic Determination of Heavy Metal Speciation in Natural Water," Analytical and Bioanalytical Chemistry, Vol. 375, No. 8, 2003, pp. 10831088.

[20] O. Zaporozhets and R. Linnik, "Hyphenated Techniques in Speciation Analysis of Metals in Natural Waters," 2004. http://www.ecotest.univ.kiev.ua/nauka/speciation_e.htm

[21] A. L. Rosen and G. M. Hieftje, "Inductively Coupled Plasma Mass Spectrometry and Electrospray Mass Spectrometry for Speciation Analysis: Applications and In- 
strumentation," Spectrochimica Acta Part B: Atomic Spectroscopy, Vol. 59, No. 2, 2004, pp. 135-146. http://dx.doi.org/10.1016/j.sab.2003.09.004

[22] A. Tessier, P. Campell and M. Bison, "Sequential Extraction Procedure for the Speciation of Particulate Trace Metals," Analytical Chemistry, Vol. 51, No. 7, 1979, pp. 844-850. http://dx.doi.org/10.1021/ac50043a017

[23] L. M. Shuman, "Fractionation Method for Soil Micronutrients," Soil Science, Vol. 140, No. 1, 1985, pp. 11-22. http://dx.doi.org/10.1097/00010694-198507000-00003

[24] A. Ure, P. Quevaullier, H. Muntau and B. Griepink, "Speciation of Heavy Metals in Soils and Sediments. An Account of the Improvement and Harmonization of Extraction Techniques Undertaken under the Auspices of the BCR of the CEC," International Journal of Environmental Analytical Chemistry, Vol. 51, No. 1-4, 1993, pp. 135-151. http://dx.doi.org/10.1080/03067319308027619

[25] G. Sposito, "The Chemical Forms of Trace Metals in Soils," In: I. Thornton, Ed., Applied Environmental Geochemistry, Academic Press, London, 1983, pp. 123-170.

[26] P. H. T. Beckett, "The Use of Extractants in Studies on the Trace Metals in Soils, Sewage Sludges and SludgeTreated Soils," Advances in Soil Sciences, Vol. 9, No. 5, 1988, pp. 144-175.

[27] A. H. Mahvi, "Application of Agricultural Fibers in Pollution Removal from Aqueous Solution," International Journal of Environmental Science and Technology, Vol. 5, No. 2, 2008, pp. 275-285. http://dx.doi.org/10.1007/BF03326022

[28] W. M. Gitari, L. F. Petrik, D. L. Key and C. Okujeni, "Partitioning of Major and Trace Inorganic Contaminants in Fly Ash Acid Mine Drainage Derived Solid Residues," International Journal of Environmental Science and Technology, Vol. 7, No. 3, 2010, pp. 519-534. http://dx.doi.org/10.1007/BF03326161

[29] P. Adamo, S. Dudka, M. Wilson and W. McHardy, "Chemical and Mineralogical Forms of $\mathrm{Cu}$ and $\mathrm{Ni}$ in Contaminated Soils from the Sudbury Mining and Smelting Region, Canada," Environmental Pollution, Vol. 91, No. 1, 1996, pp. 11-19. http://dx.doi.org/10.1016/0269-7491(95)00035-P

[30] L. Q. Ma and G. N. Rao, "Chemical Fractionation of Cadmium, Copper, Nickel and Zinc Contaminated Soils," Journal of Environmental Quality, Vol. 26, No. 1, 1997, pp. 259-264.

[31] F. Mohsenzadeh, J. Nouri, A. Ranjbar, F. Mohammadian and A. Babaie, "Air Pollution Control through Kiln Recycling By-Pass Dust in a Cement Factory: Iran," Journal of Environmental Health Science and Engineering, Vol. 3, No. 1, 2006, pp. 5-8. http://dx.doi.org/10.2134/jeq1997.0047242500260001003 $\underline{6 x}$

[32] A. R. Karbassi, S. M. Monavari, G. R. Bidhendi, J. Nouri and K. Nematpour, "Metal Pollution Assessment of Sediment and Water in the Shur River," Environmental Monitoring and Assessment, Vol. 147, No. 1-3, 2008, pp. 107-116. http://dx.doi.org/10.1007/s10661-007-0102-8

[33] X. D. Feng, Z. Dang, W. Huang and C. Yang, "Chemical Speciation of Fine Particle Bound Trace Metals," Inter- national Journal of Environmental Science and Technology, Vol. 6, No. 3, 2009, pp. 337-346.

[34] B. Nowak, "Sequential Extraction of Metals Forms in the Soil near a Roadway in Southern Poland," Analyst, Vol. 120, No. 3, 1995, pp. 737-739. http://dx.doi.org/10.1039/an9952000737

[35] R. E. Jervis, S. S. Krishna, M. M. Ko, L. D. Vela, T. G. Pringle, A. C. Chan and L. Xing, "Biological Incinerator emission of Toxic Inorganics, Their Residues and Their Availability," Analyst, Vol. 120, No. 3, 1995, pp. 651-658. http://dx.doi.org/10.1039/an9952000651

[36] G. S. R. Krishnamurti, P. M. Huang, K. C. J. Van Rees, L. M. Kozak and H. P. W. Rostad, "Speciation of Particulate-Bound Cadmium of Soils and Its Bioavailability," Analyst, Vol. 120, No. 3, 1995, pp. 659-665. http://dx.doi.org/10.1039/an9952000659

[37] C. M. Davidson, P. C. S. Ferreira and A. M. Ure, "Some Sources of Variability in Application of the Three-Stage Sequential Extraction Procedure Recommended by BCR to Industrially-Contaminated Soil," Fresenius' Journal of Analytical Chemistry, Vol. 363, No. 5-6, 1999, pp. 446451. http://dx.doi.org/10.1007/s002160051220

[38] A. Moc'ko and W. Wacławek, "Three-Step Extraction Procedure for Determination of Heavy Metals Availability to Vegetables," Analytical and Bioanalytical Chemistry, Vol. 380, No. 5-6, 2004, pp. 813-817. http://dx.doi.org/10.1007/s00216-004-2832-6

[39] H.-S. Jung, S.-T. Yun, B.-Y. Choi, H.-M. Kim, M. Jung, S.-O. Kim and K.-H. Kim, "Geochemical Studies on the Contamination and Dispersion of Trace Metals in Intertidal Sediments Around a Military Air Weapons Shooting Range," Journal of Soils and Sediments, Vol. 10, No. 6, 2010, pp. 1142-1158.

http://dx.doi.org/10.1007/s11368-010-0248-9

[40] R. Pöykiö, P. Perämäki, I. Välimäki and T. Kuokkanen, "Estimation of Environmental Mobility of Heavy Metals Using a Sequential Leaching of Particulate Material Emitted from an Opencast Chrome Mine Complex," Analytical and Bioanalytical Chemistry, Vol. 373, No. 3, 2002, pp. 190-194. http://dx.doi.org/10.1007/s00216-002-1299-6

[41] T. Peytoni, A. Mcintosh, V. Anderson and K. Yost, "Aerial Input of Heavy Metals into an Aquatic Ecosystem," Water, Air and Soil Pollution, Vol. 5, No. 4, 1976, pp. 443-451. http://dx.doi.org/10.1007/BF00280845

[42] E. Z. Ochieng, J. O. Lalah and S. O. Wandiga, “Anthroponic Sources of Heavy Metals in the Indian Ocean Coast of Kenya," Bulletin of Environmental Contamination and Toxicology, Vol. 83, No. 4, 2009, pp. 600-607. http://dx.doi.org/10.1007/s00128-009-9807-4

[43] J. O. Lalah, E. Z. Ochieng and S. O. Wandiga, "Sources of Heavy Metal Input into Winam Gulf, Kenya," Bulletin of Environmental Contamination and Toxicology, Vol. 81, No. 3, 2008, pp. 277-284. http://dx.doi.org/10.1007/s00128-008-9452-3

[44] C. K. Jain, "Metal Fractionation Study on Bed Sediments of River Yamuna, India," Water Research, Vol. 38, No. 3, 2004, pp. 569-578. http://dx.doi.org/10.1016/j.watres.2003.10.042

[45] J. L. Trujillo-Cárdenas, N. P. Saucedo-Torres, P. F. 
Zárate del Valle, N. Ríos-Donato, E. Mendizábal and S. Gómez-Salazarb, "Speciation and Sources of Toxic Metals in Sediments of Lake Chapala, Mexico," Journal of the Mexican Chemical Society, Vol. 54, No. 2, 2010, pp. 79-87.

[46] M. J. Kennish, "Ecology of Estuaries: Anthropogenic Effects," CRC, Boca Raton, 1992.

[47] S. R. Stephens, B. J. Alloway, J. E. Carter and A. Parker, "Towards the Characterization of Heavy Metals in Dredged Canal Sediments and an Appreciation of Availability: Two Examples from the UK," Environmental Pollution, Vol. 113, No. 2, 2001, pp. 395-401. http://dx.doi.org/10.1016/S0269-7491(00)00178-0

[48] J. N. Egila and D. N. Nimyel, "Determination of Trace Metal Speciation in Sediments from Some Dams," Journal of Chemical. Society of Nigeria, Vol. 27, No. 1, 2002, pp. 71-77.

[49] S. V. Matagi, D. Swai and R. Mugabe, "Heavy Metal Remove/Mechanisms in Wetlands," African Journal of Tropical Hydrobiology and Fisheries, Vol. 8, 1998, pp. 23-35.

[50] M. Kersten and U. Forstner, "Chemical Fractionation of Heavy Metals in Anoxic Estuarine and Coastal Sediments," Water Science and Technology, Vol. 18, No. 4-5, 1986, pp. 121-130.

[51] W. Calmano, J. Hong and U. Forstner, "Binding and Mobilisation of Heavy Metals in Contaminated Sediments Affected by $\mathrm{pH}$ and Redox Potential," Water Science and Technology, Vol. 28, No. 8-9, 1993, pp. 223-235.

[52] D. W. Engel, W. G. Sunda and B. A. Fowler, "Factors Affecting Trace Metal Uptake and Toxicity to Estuarine Organisms. I. Environmental Parameters,” In: J. F. Vernberg, A. Calabrese, F. P. Thurberg and W. B. Vernberg, Eds., Biological Monitoring of Marine Pollutants, Academic Press, New York, 1981, pp. 127-143. http://dx.doi.org/10.1016/B978-0-12-718450-0.50011-0

[53] D. C. Adriano, "Trace Elements in Terrestrial Environment-Biogeochemistry, Bioavailability, and Risks of Metals," 2nd Edition, Springer, New York, 2001. http://dx.doi.org/10.1007/978-0-387-21510-5

[54] J. E. Fergusson, "The Heavy Elements: Chemistry of Environmental Impact and Health Effects," Pergamon Press, Oxford, 1990.

[55] Q. X. Zhou and Y. F. Song, "Remediation of Contaminated Soils: Principles and Methods," Science Press, Beijing, 2004, pp. 135-141.

[56] G. L. Guo, Q. X. Zhou and L. Q. Ma, "Availability and Assessment of Fixing Additives for the in Situ Remediation of Heavy Metal Contaminated Soils: A Review," Environmental Monitoring and Assessment, Vol. 116, No. 13, 2006, pp. 513-528. http://dx.doi.org/10.1007/s10661-006-7668-4

[57] C. F. Lin, S. S. Lo, H. Y. Lin and Y. C. Lee, "Stabilization of Cadmium Contaminated Soils Using Synthesized
Zeolite," Journal of Hazardous Materials, Vol. 60, No. 3, 1998, pp. 217-226.

[58] K. Fytianos, G. Katsianis, P. Triantafyllou and G. Zachariadis, "Accumulation of Heavy Metals in Vegetables Grown in an Industrial Area in Relation to Soil," Bulletin Environmental Contamination and Toxicology, Vol. 67, No. 3, 2001, pp. 423-430. http://dx.doi.org/10.1007/s001280141

[59] Q. X. Zhou and G. H. Huan, "Environmental Biogeochemistry and Global Environmental Changes," Science Press, Beijing, 2001.

[60] I. M. C. Lo and X. Y. Yang, "Removal and Distribution of Metals from Contaminated Soils by a Sequential Extraction Method," Waste Management, Vol. 18, No. 1, 1998, pp. 1-7.

http://dx.doi.org/10.1016/S0956-053X(97)10005-8

[61] D. Peakall and J. Burger, "Methodologies for Assessing Exposure to Metals: Speciation, Bioavailability of Metals, and Ecological Host Factors," Ecotoxicology and Environmental Safety, Vol. 56, No. 1, 2003, pp. 110-121. http://dx.doi.org/10.1016/S0147-6513(03)00055-1

[62] J. M. Scheyer, "Estimating Dietary Risk from Soils in Urban Gardens," In: W. Burghardt and C. Dornauf, Eds., Proceedings of the First International Conference on Soils of Urban, Industrial, Traffic, and Mining Areas, Essen, 2000, pp. 479-484.

[63] R. Cornelis, "Speciation of Trace Elements: A Way to a Safer World," Analytical and Bioanalytical Chemistry, Vol. 373, No. 3, 2002, pp. 123-124.

[64] P. C. Ryan, S. Hillier and A. J. Wall, "Stepwise Effects of the BCR Sequential Chemical Extraction Procedure on Dissolution and Metal Release from Common Ferromagnesian Clay Minerals: A Combined Solution Chemistry and X-Ray Powder Diffraction Study," Science of the Total Environment, Vol. 407, No. 1, 2008, pp. 603-614. http://dx.doi.org/10.1016/j.scitotenv.2008.09.019

[65] E. Galán, J. L. Gómez Ariza, I. González, J. C. Fernández Caliani, E. Morales and I. Giráldez, "Utility of the Techniques of Sequential Extraction in the Improvement of the Mineralogica Characterization by DRX of Grounds and Sediments with High Contents of Iron Oxides," In: Book of Lectures and Summaries of XV the Scientific Meeting of the Spanish Clay Society, 1999, pp. 68-69.

[66] I. Maiz, I. Arambarri, R. Garcia and E. Millán, "Evaluation of Heavy Metal Availability in Polluted Soils by Two Sequential Extraction Procedures Using Factor Analysis," Environmental Pollution, Vol. 110, No. 1, 2000, pp. 3-9. http://dx.doi.org/10.1016/S0269-7491(99)00287-0

[67] A. J. Zimmerman and D. C. Weindorf, "Heavy Metal and Trace Metal Analysis in Soil by Sequential Extraction: A Review of Procedures," International Journal of Analytical Chemistry, Vol. 2010, No. 2010, 2010, Article ID: 387803. http://dx.doi.org/10.1155/2010/387803 